\title{
Critical Arts
}

\section{Beyond Rebellion of the Net: Infrastructural Commoning as Critical Cultural Literacy}

\section{Gabriela Méndez Cota \& Alberto López Cuenca}

To cite this article: Gabriela Méndez Cota \& Alberto López Cuenca (2020) Beyond Rebellion of the Net: Infrastructural Commoning as Critical Cultural Literacy, Critical Arts, 34:5, 24-38, DOI: $10.1080 / 02560046.2020 .1779326$

To link to this article: https://doi.org/10.1080/02560046.2020.1779326

册 Published online: 10 Jul 2020.

Submit your article to this journal $₫$

山ll Article views: 116

Q View related articles ๘

View Crossmark data 


\title{
Beyond Rebellion of the Net: Infrastructural Commoning as Critical Cultural Literacy
}

\author{
Gabriela Méndez Cota $\mathbb{D}^{\mathrm{a}}$ and Alberto López Cuenca (1D ${ }^{\mathrm{b}}$ \\ a Universidad Iberoamericana, Mexico City, Mexico; ${ }^{\mathrm{b}}$ Benemérita Universidad Autónoma de Puebla, Mexico
}

\begin{abstract}
This article offers a critical interpretation of the recent cultural and political history of artistic engagements with digital technologies in contemporary Mexico, considering some of them in relation to changing notions of cultural literacy under neoliberal globalization. While educational social research in Latin America has its own critical traditions for studying literacy as a social practice embedded in power relations, art theory and criticism in Mexico and abroad have barely raised the question of new media art's specific relevance to questions of literacy. Through a cultural and media studies lens acting as a bridge between art theory and criticism on the one hand, and educational research on literacy on the other hand, this article shows how, during the neoliberal conjuncture, artistic engagements with digital technologies articulated cultural experimentation with grassroots political struggles and mediated wider processes of economic and technological transformation. We suggest that new media art, as a post-autonomous practice in times of transition, introduced questions of digital commoning as concerns for cultural literacy in a broad sense. We argue, however, for a non-instrumental and open-ended infrastructural understanding of art's educational role in relation to ongoing historical conjunctures.
\end{abstract}

\section{KEYWORDS}

New media art; Mexico; digital commoning; infrastructure; cultural analytic of technology; digital literacies

\section{Introduction: what is art like?}

In July 2017 the Zapatista Army of National Liberation (EZLN) held the 2nd CompArte or "ShareArt" Festival for Humanity in San Cristóbal de las Casas, Chiapas. A gathering of anti-capitalist artists and activists loyal to the Zapatista struggle for indigenous self-government, CompArte released a call for proposals including a digital section entitled "Art, Resistance and Rebellion of the Net". There readers would find rhetorical questions that opposed a traditional conception of art as an autonomous sphere uncontaminated by politics to a conception that identifies art with militant struggles:

... What is that Art like? Can it rebel? [...] Does Art on, by, and for the net trivialize and banalize the struggle, or does it potentiate it and scale it up, or is it "totally unrelated, my friend; it's art, not a militant cell"? (Enlace Zapatista 2017) 
Curiously enough, CompArte's bet on rebellion and militancy fits well in a recognizable history and philosophy of art that defines art's condition as contemporary. As Frank Maet (2013) aptly summarizes, a conceptual as well as a practical tension between autonomy and post-autonomy came to define contemporary art during the twentieth century. Such a tension encompasses "Art on, by, and for the Net" whether we choose to include it in a history narrated from a hegemonic "Northern" perspective (Smith 2009), or in one narrated from a critical "Southern" perspective (Giunta 2014). Yet clearly CompArte calls for something different to more post-autonomous "Art". It seems to instead call for a fresh investigation into the latter's specific political capacities at the grassroots level in a context where the grassroots lives in open conflict with the state, which includes the institutions of culture and the arts. And it is in a further tension between the militant demands of grassroots struggles on the one hand, and the critical distance of scholarly analysis of the neoliberal conjuncture on the other hand, that we situate our contribution to a reflection on cultural literacy in a Mexican context. We offer an indirect response to the questions posed by CompArte that consists of a partial reconstruction of the story of new media art in Mexico, through which we hope to illuminate a political dimension of postautonomous art practices beyond a militant "rebellion of the Net". Neither "Art" nor a "militant cell", such practices inform changing notions of cultural literacy in times of transition (Berlant 2016) (Figure 1).

Given our interest in the political dimension of artistic practices, why try to go beyond a militant "rebellion of the Net"? A short answer here is our concern about instrumentalism, or the use of art as a mere representational tool or vehicle for pre-established political meanings-a militant gesture par excellence. As an alternative, we attempt to situate some post-autonomous art practices (initially known as "new media art") within a cultural analytic of technology. Such an analytic seeks to understand, following Mark Poster (2006, 139), how new media "enable practices that fit badly with earlier complexes of domination,

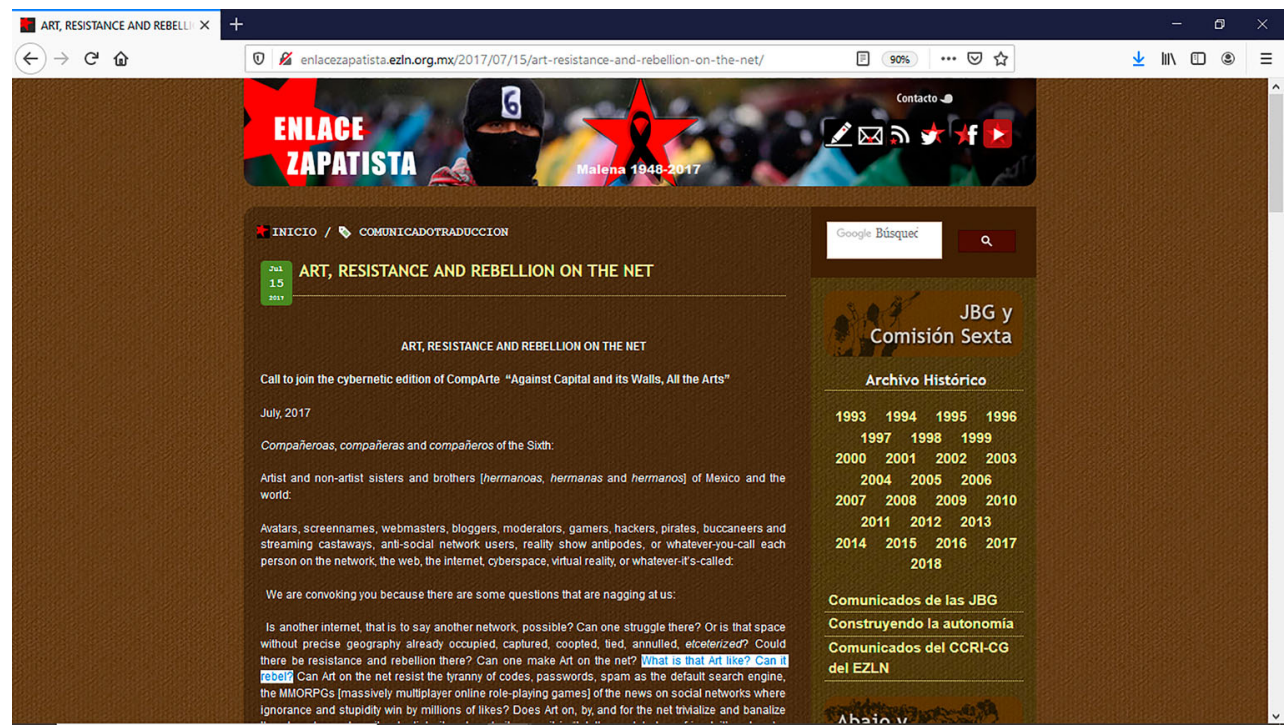

Figure 1. CompArte's 2017 Call for proposals. Accessed on 30th December, 2019. 
putting them into question and thereby opening the field [...] to new spaces of politics". It follows that a cultural analytic of technology necessarily involves a risk, a step into the unfamiliar with respect to pre-existing notions of individual and collective identities as well as that of technology itself. Without taking such a step, Poster $(2006,135)$ says, the study of new media is at risk of incorporating, by default, the culture of the dominant institutions of society. Here, we pay heed to Poster's warning and take a step into the unfamiliar by not just describing how Mexican new media art opened new spaces for political activism, but also by questioning the meaning of "political" in artistic activism, and by actively relating the politicality of new media art to changing notions of cultural literacies.

Our cultural analytic of technology is preceded in this article by a short introductory section on literacies research in Latin America. There we establish as our starting point the fact that, while critical social research in Latin America has its own critical traditions of studying literacy as a social practice embedded in power relations, "culture and the arts" in general, and contemporary post-autonomous art in particular, have not been directly regarded as high priority issues in education research. Moreover, in research contexts marked by the scars of colonization, the meaning and relevance of cultural literacy is a question rather than a comfortable given-hence, perhaps, CompArte's sarcastic rhetoric on "Art". By reconstructing, in the second section, the recent story of Mexican new media art in the neoliberal conjuncture, our cultural analytic of technology suggests a change in expectations regarding the work of art and artists in relation to technology, politics, and state-sponsored art education. Acting as a new bridge between contemporary artistic and educational discourses, our cultural analytic of technology looks at the novelties introduced by media art's mediation of wider processes of economic and technological transformation in Mexico. In the third section, we frame some examples of new media art's critical mediation of social change through notions of commoning and infrastructuring, arguing that these notions have a key role to play in critical appropriations of cultural literacy discourse, which we frame here as new spaces of politics, in a practical sense. We conclude by offering some thoughts on what we see as the need of a more nuanced and open-ended understanding of literacy than we find in current discourses of commoning and infrastructural processes in contemporary art.

\section{Whose culture, whose literacies?}

From a Northern perspective it might seem it was with the New London Group (1996) that literacy was no longer conceived as the mechanical acquisition of merely cognitive technical skills for reading and writing, coming to be regarded instead as "a process of socialization situated in the context of the power structures of society and its institutions" (Rutten, Rodman, and Soetaert 2013, 445). Such an insight generated terms like "multiliteracies", which associated the notion of literacy with the project of becoming politically conscious in a newly technologized multicultural age. Yet well before the 1990s, Latin America had developed its own critical resources for studying literacy as socially embedded, politically charged and multiple. Drawing on concerns about the geopolitics of knowledge in literacy research, Trigos-Carrillo and Rogers (2017) provide a comprehensive analytical review of multiliteracies scholarship in Latin America, from which we would like to highlight only a few details by way of contextualization. First, it is true that until 2004, the only term available for translating "literacy" was alfabetización, denoting the 
narrow, now old-fashioned, understanding of alphabetical literacy. Such a notion was instrumental to both revolutionary struggles and to nation-building state projects seeking social modernization in Latin America (Kalman and Reyes 2017). Yet as early as 1965 the neo-colonial uses of alfabetización were challenged by Brazilian philosopher Paulo Freire (1970), whose widely renowned "pedagogy of the oppressed" developed the basic insight that literacy involves politically conscious self-transformation. In Mexico, philosopher and theologian Iván Illich (1971) proposed to "deschool society" through a critical analysis of writing technologies and a communal reorientation of technological literacy. In the 1980 s, something like a notion of multiliteracies was prefigured in the groundbreaking work of the Spanish-Colombian philosopher Jesús Martín Barbero, who re-oriented communication research towards an exploration of the multiple "mediations" of popular culture (Marroquín Parducci 2017, 28). Contemporary Latin American research on multiliteracies has expanded and diversified across disciplinary fields, drawing increasingly from global multiliteracies research without losing a distinctive Latin American focus on the oppressed. Indigenous, bilingual and intercultural literacies therefore constitute current priorities in educational research agendas, followed by studies of digital literacy in marginalized communities (Trigos-Carrillo and Rogers 2017, 380-382).

What stands out from the above is a gap in Latin American research on multiliteracies regarding arts education, since neither art nor aesthetic issues appear in Trigos-Carrillo and Rogers's comprehensive review on multiliteracies research. The views of arts education experts compound this impression when they point out that in Mexico "a lack of systematic and reputable research about arts education" is due to "lack of interest amongst researchers, either educators or art historians" (Dias et al. 2017, 166). The latter, they continue, have "focused on the study of art and artists leaving aside the creation of audiences and art spectators" (166). ${ }^{1}$ If cultural literacy means fluent knowledge and informed appreciation of the main artistic referents in a national culture, all we could say based on local and regional research is that levels of cultural literacy in Mexico probably reflect how little Mexicans in general actually learn about culture and the arts through reading and writing in the traditional sense (Ollé-Laprune 2011). However, international debates (Kellner and Share 2005) have broadened the understanding of cultural literacy to the point that the notion now encompasses all "skills and practices that are relevant to the changing dynamics of modern life" (Shliakhovchuk 2019, 2). We identify two major trends in this broadening, one that inscribes cultural literacy in universalizing economic discourse-for instance, UN discourses of sustainable development (Shliakhovchuk 2019) — and a cultural studies trend that privileges a critical and politically transformative approach to literacies in specific contexts (Rutten, Rodman, and Soetaert 2013). Within this second trend, our cultural analytic of technology asks about the opening of new spaces for political practice through the post-autonomous artistic field of new media and technological art in Mexico (Jasso and Garza Usabiaga 2010; Aedo 2015). We take into account that, while Mexican official discourses on literacy continue to draw on the high-culture and book-centred legacy of alfabetización, anthropologists and communication researchers working in the tradition of cultural studies (García Canclini 2015) have come to share with some education researchers (Kalman and Reyes 2017) the critical mission of refuting

${ }^{1}$ One exception to this is Graciela Schmilchuk, Rosas Mantecón, and Piccini (2000). 
traditional lamentations that Mexican's do not read (Ollé-Laprune 2011). By focusing here on new media art, which is for us a question of culture and power, ${ }^{2}$ we hope to contribute a theoretical approach to cultural literacy in the Mexican context, in the specific sense of "the work of theorizing in relation to the ongoing analysis of changing historical conjunctures" (Poster 2006, 145).

\section{New media art between neoliberalism and anti-capitalism}

Mexican artistic engagements with new digital media took off in the 1990s with the support of state institutions in a time of heightened political conflict and globalized technological enthusiasm. The first of such institutions was Centro Multimedia (CM), which opened in 1994, the year the North American Free Trade Agreement (NAFTA) went into effect. NAFTA provided the legal framework for the neoliberal restructuring of the Mexican economy, an early example of which is precisely the telecommunications sector, which was sold out to private enterprise since 1990 (Martínez Velázquez 2017). Unlike the telecommunications infrastructure, culture and the arts were not directly sold out by neoliberal governments. These instead drew on the long-standing Mexican tradition of state patronage of culture and the arts for hegemonic ends (Ollé-Laprune 2011). Cultural nationalism had been key to the authoritarian regime that ruled Mexico for almost a century, and being themselves the offspring of that regime, neoliberal elites understood that they had to reconfigure nationalism rather than discard it if they were to succeed in promoting the country's neoliberal restructuring. Mexican neoliberals did not discard nationalism but reframed it in terms of "competitive strength", understood as that which would lead Mexico, according to then President Carlos Salinas de Gortari (1988-1994), to being "part of the First World and not of the Third" (O'Toole 2003, 283). It was the distinctive role of techno-enthusiasm in the neoliberal agenda of "competitive strength", rather than privatized telecommunications, which more directly explains the founding of Centro Multimedia as the first public institution that would host and actively promote new media art in Mexico.

Located within the National Centre for the Arts (Cenart), a monumental complex that also hosts the national schools and research centres on theatre, music, dance and visual arts, CM can be regarded as a major example of neoliberal cultural policy. Andrea di Castro $(2006,372)$, its first director from 1994 to 2001, wrote that the goal of CM was to produce "electronic art" that would resonate with international trends represented by the Banff Center for the Arts and the McLuhan Program of the University of Toronto, "our main interlocutors and accomplices". Young Mexican artists would receive grants and take part in workshops, residencies and festivals hosted by CM, in which they would be able to experiment with the latest technologies, presumably those developed in advanced technology centres. Pedagogically, Centro Multimedia aimed to operate "in the tradition of the artist's studio, where the master plans the activities and the

\footnotetext{
${ }^{2}$ What is known in North America as Latin American studies of culture and power is today regarded as having had a "turn to cultural studies," one of the most recent reviews of which is found in Juan Poblete's (2018) anthology. An anthology as recent and important as Poblete's does not include anything like "the new media and digital culture turn" or even "the turn to contemporary art", suggesting that art and technology have not been officially regarded as relevant topics within Latin American studies of culture and power. This is surprising since some of the most innovative practitioners, such as the scholar and creative writer Cristina Rivera Garza (2013), have demonstrated the urgency of linking technologically mediated practices of reading and writing with urgent social and political questions for the Latin American Humanities.
} 
apprentices follow his/her directions" (Di Castro 2006, 372). Yet such an early focus on high technology, combined with a traditional understanding of art and art education, clearly resonated less with international trends in artistic experimentation and theory, than with the discursive agenda of a neoliberal government that sought to promote Mexico's entry into global competition. Hence, the enthusiastic promotion of new media art was at least partly instrumental to the neoliberal agenda of reframing national culture in terms of "competitive" attractiveness for international business and investment (Emmelhainz 2016).

In the same year that CM started its operations, the indigenous Zapatista insurrection directly challenged the rhetorical strategy of neoliberal governments through an indigenous-based communal vision of culture and politics. By means of a collaborative and strategic use of electronic networks (Martínez-Torres 2001), the Zapatista rebels succeeded in harnessing the anti-capitalist support of millions in Mexico and abroad, and their success remains iconic of the early Internet's political promises of participatory and non-hierarchical forms of self-organization (Conant 2010). Since 1996, new media artists were among the most heavily invested in supporting the Zapatista-inspired uprising of electronic networks. On the "militant" side of art, in 1998 the Electronic Disturbance Theater designed and executed the FloodNet application for launching "massive sit-ins" that would block the webpages of Mexican President Ernesto Zedillo, the Pentagon, or the Frankfurt Stock Exchange. ${ }^{3}$ Yet from the start there was more than straightforward militancy in new media art. Projects such as rhizome.org and irational.org took up questions about the kinds of social relations that digital networks made possible, and promptly appropriated the political communication strategies of the Zapatista rebels. While Rhizome.org was originally an email list for discussion and information exchange for artists interested in the Web as an art medium (Wolf 2006, 47-48), irational.org was a platform for deploying information, services and products "for the displaced and roaming", that is, for independent artists and organizations that needed to maintain "mission-critical information systems" (Ackers et al. 2006, 66). On the same year that FloodNet took place, Mexican artist Minerva Cuevas launched Mejor Vida Corp. (MVC) through the irational.org platform. MVC was a fake corporation offering to clean subway station platforms, issue reference letters and give away products such as safety pills, magic seeds or student ID cards. More than on documenting a "rebellion of the Net" sparked by Zapatista enthusiasm in the 1990s, we are interested on figuring out the political spaces opened by new media experiments such as MVC. Here, we propose to read the opening of new political spaces through an infrastructural perspective that essentially relates artistic practices with changing notions of cultural literacy.

At any rate, we do not regard Mexican new media art as independent from the cultural policies and institutions of the neoliberal state. CM promptly adjusted its educational mission to the Zapatista-inspired agenda of struggle "on, by, and for the Net". After di Castro left the directorship of CM in 2001, pioneer new media artists, professional arts administrators and researchers such as Tania Aedo, Lilia Pérez Romero, Grace Quintanilla, Liliana Quintero, Adriana Casas, and Karla Jasso, took up a leading role in redefining CM's goals and pedagogical aims. Collectively they problematized CM's early focus on high

\footnotetext{
${ }^{3}$ For a more detailed consideration of the artistic work and digital activism of the Electronic Disturbance Theatre supporting EZLN, see Lane and Domínguez (2003).
} 
technology and worked towards an alternative focus on the cultural politics of digital media, on the relevance of low-tech for a Latin American standpoint, as well as on theoretical reflection around the philosophical significance of new media arts beyond hardware. Artists inspired by Zapatismo such as Fran Ilich and Eugenio Tisselli participated quite actively in the development of study groups and electronic art festivals-the most important of which was Transitio_MX (2005-2017) —articulating their artwork with the promotion of philosophical critiques of technological determinism and political reflections around new media uses in Mexico (Quintero Álvarez 2010). Indeed, from a narrow focus on "electronic arts" in the 1990s, Centro Multimedia came to host the "First National Forum on Technological Re-Writings" in 2016, which gathered grassroots communities from well beyond the new media art field to discuss the emancipatory possibilities of a critical socialization of new technologies. In the memoir of the event, Tisselli $(2016,10$; see 9-17) explains: "cultural values inscribed in technological artifacts are not fixed; it is possible to re-write them through social processes that can be understood as forms of political negotiation". We interpret this evolution of new media art toward critical cultural literacy as indissociable from the specific institutional processes and cultural arrangements of the Mexican neoliberal conjuncture.

Globally, there has been a notorious amount of research on socially engaged, participatory and collaborative art (Kester 2004; Lind 2007; Sholette and Stimson 2007; Bishop 2012; Geocomunes 2018). In Mexico, such developments have had less to do with critical multiliteracies research in the Latin American context than with global trends in the commodification of culture, among them the active interest of hegemonic cultural institutions in radical or "militant" art. Minerva Cuevas's MVC eventually circulated as a digital platform for institutional parody in legitimate cultural venues in Mexico City such as Museo Tamayo, Centro de la Imagen and Museo de Arte Carrillo Gil, among others internationally. With the arrival and expansion of social media between 2003 and 2006, the artistic "rebellion on the Net" turned increasingly to pedagogical experiments with participation (Barney et al. 2016) and collaboration (Amgott 2018) which were above all about setting social processes in motion (Graham and Cook 2010, 5). More recently, something like the 2006 "Educational Turn" documented by Graham, Graziano, and Kelly (2016) for Europe seems to have taken hold in Mexico City through the public programming in contemporary art museums (Jiménez 2019). The success of "militant" art and the local instantiation of the Educational Turn might be symptomatic of

a deeper problem in art institutions since at least the 1990s, where radical ideas have been increasingly packaged as a new kind of "content capitalism", deliberately separated from their immediate contexts and the politics that they name. (Graham, Graziano, and Kelly 2016, 30)

Moreover, since there is no natural articulation between the urban audiences of contemporary art (however "militant") and the oppressed communities that have traditionally concerned Latin American research on multiliteracies, it remains to be seen whether Mexican new media art, recognizable as such only in the context of globally oriented art institutions, can by itself eschew a critique of the Educational Turn:

If what is hidden in the curriculum of the Educational Turn is the practice of detachment, the consumption of knowledge and the attribution of its place away from the "tending of common affairs" of democratic agency, then what we learn is to avoid social and political antagonism, to abandon the implications of what we read and learn and to disregard 
struggles of radical education in the name of producing yet more privatized cultural capital. $(2016,32)$

The spirit of this critique resonates very clearly with CompArte's questions, which seem worth reiterating at this point: "Does Art on, by, and for the net trivialize and banalize the struggle, or does it potentiate it and scale it up, or is it 'totally unrelated, my friend; it's art, not a militant cell'?" Clearly, an understanding of political struggle in terms of militancy does not save new media art from trivializing or banalizing such a struggle. In fact, a narrow understanding of political struggle in terms of militancy makes it difficult to theorize new political spaces or practices, which we regard as closely linked to the specific labour of art in relation to the tending of common affairs of democratic agency. In this regard, Minerva Cuevas in conversation with Gustavo Abaroa $(2013,171)$ once noted that "art can generate unique sensorial, scientific and technological exercises as well as a stronger sense of community, [...] by means of unlimited creative resources and interdisciplinary connections". Rather than quickly dismissing "art" as a trivialization or banalization of real political struggle, we could explore changing notions of art as changing notions of cultural literacy that now foreground the tending of common affairs through unique exercises in social relations, and these changing notions as new spaces of politics in relation to prior notions of self. As a statesponsored educational centre for art and technology, in which multiple actors converged from Mexico's culture and the arts scene, Centro Multimedia operated as a laboratory of cultural transformation from which at least one novelty emerged, one encapsulated in Tisselli's notion of technological re-writing as political intervention.

\section{New spaces for cultural literacy: art, commoning and infrastructuring}

Peter Linebaugh invokes the 1994 Zapatista insurrection as a key moment in the recent history of commons discourse, a discourse that is not simply about the communal property of material resources, but most importantly it is about governance or "collective ways of doing at the crossroads of people and things" (Linebaugh 2014, 118). As early as 1995, the traditional stress on environmental governance in commons discourse gave way to issues of technological governance and intellectual property (Hess 2008, 2-3). The notion of a "digital commons" emerged and opened avenues for the current expansion of "commoning", a term that today refers to dynamics as complex and disparate as a revolutionary movement in Mexico, a second enclosure movement, the intelligent multitudes, neighbourhood associations or peer-to-peer production (Bollier and Helfrich 2012; de Angelis 2017). We propose to think of "Art on, by, and for the Net" not exclusively in terms of rebellion but more fruitfully in terms of digital commoning processes as political spaces explored by "critical makers of social form" (Berlant 2016). Included in social form would be new notions of cultural literacy, and here we are especially interested in those related to the democratic tending of common affairs. In what follows, we draw on the resonances between theories of digital commoning and critical studies of infrastructuring processes in order to analyse some examples of artistic engagements with new media technologies as changing practices in cultural literacy.

Closely related to digital commoning is an infrastructural understanding of media, which focuses on materialities, processes of distribution, and social and epistemic enquiry (Parks and Starosielski 2015). As theorized by philosopher John Durham Peters, digital media are unlike the mass media of the twentieth century in that they "traffic 
less in content, programs, and opinions than in organization, power, and calculation"; they do not as much provide unifying stories to the society at large as they serve as "logistical devices of tracking and orientation" (Peters 2015, 7). By understanding the work of all media as fundamentally logistical, Peters advocates an "infrastructuralist" perspective on the technological world at large that pays attention to often implicit phenomena such as how media "coordinate and subordinate, arranging relationships among people and things" $(2015,37)$. Well before Peters's media philosophy, STS perspectives on infrastructure had begun to develop out a relational and processual ontology (Bowker and Star 2002) that underlies the current use of "infrastructuring" as a verb, instead of "infrastructure" or even "infrastructures" as a noun (Karasti, Pipek, and Bowker 2018). A pioneer of critical studies of media infrastructures, Lisa Parks $(2015,357)$ argues that media must be read with an infrastructural disposition, that is, thinking not only about what media represent but, "more elementally about what they are made of and how they arrived". This kind of reading is oriented towards "the relation between technological literacies and public involvement in infrastructure development, regulation, and use" (Parks and Starosielski 2015,6 ). In other words, technological literacy as critical media infrastructuring contextualizes and renders visible the fragility of infrastructures, their need for labour, repair, and maintenance, within the frame of an ontologically enriched epistemology (13).

Artistic practices thus have a privileged place in the innovative methodologies of critical media infrastructures research. Parks's $(2015,356)$ own methodological focus on the materiality of specific locations, site visits, and multiple visualizations is appreciative of the pedagogical value of artistic initiatives, insofar as the latter foster intelligibility, critical analysis, public curiosity and concern about infrastructures. Not surprisingly, critical trends in contemporary art practices have been actively pushing for a citizens' "right to infrastructure", and in the process have thrown into relief the need for a new form of (infrastructural) literacy (Dragona 2014; Dragona and Charitos 2018). Dragona argues that, while artists can be seen as explorers of communication architectures as well as methodological experimenters, their artistic initiatives should be seen as taking steps towards critical awareness and towards the emancipation of users. By focusing on how artistic initiatives "empower users to develop their own competencies and skills through a creative engagement with technology", she emphasizes the political dimension of "infrastructural literacy", or the fact that it is rooted in an opposition to the centralization of current network systems and technologies. Hence the methods that privilege hands-on experience with material devices, promote collective ownership through knowledge sharing and use of open source and free software, and bring back "the human element" of labour, maintenance and repair, and resort to playfulness. Regarding their expanded survey of infrastructural literacy projects undertaken by artists, and placing these initiatives in the light of pioneer thinking around the network commons, Dragona and Charitos $(2018,29)$ conclude that "commoning in the case of infrastructures is therefore a process based on the potentialities, skills and affects with the aim to own, control and maintain as a commons systems of connectivity, communication and sharing".

In Latin America there are several examples of "network practices" that could be read in terms of critical media infrastructuring. Heber Rodríguez (2016) points out that from a Latin American vantage point, new technologies appear as imposing a set of non-native cultural modes. His overview of network practices underscores efforts to comment on the politics of the web through adaptation and reconfiguration of spaces that allow for 
locally relevant interactions among communities not served by typical Internet resources. It is in fact in view of unequal access to and dependence on foreign technological infrastructures, that more and more theorists of the commons are arguing for a commoning of the infrastructural dimensions of digital media. Such was the drive behind Rhizomatica's creation, which since 2009 has sought to make, with active participation of artists, "alternative telecommunications infrastructure possible for people around the world dealing with oppressive regimes, the threat of natural disaster, or the reality of living in a place deemed too poor or isolated to be covered by commercial initiatives" (Rhizomatica, n.d.). Whereas, along these lines, Dragona emphasizes technological empowerment through technological literacy - framed in a discourse of citizen rights to infrastructures-here we would like to emphasize the critical and creative dimensions of an infrastructural disposition. An infrastructural disposition in cultural literacy has to do with the generation of new practices for thought and existence rather than with technical problem solving on behalf of pre-given communities or political selves. Lauren Berlant's $(2016,395)$ idea of the commons involves a practical "pedagogy of learning to live with messed up yet shared and ongoing infrastructures of experience". In turn, she defines infrastructure as "the movement or patterning or social form", "the living mediation of what organizes life" and "all the systems that link ongoing proximity to being in a world-sustaining relation" $(2016,393)$. We follow Berlant in understanding artists engaged in digital commoning as "critical makers of social form"; being more than tool makers and engineers, they do much more than offer representational support to existing struggles. More fundamentally, they offer "terms of transition" at times of infrastructural failure, a failure "of sociality itself" $(2016,395)$.

In view of depoliticizing tendencies at work in dominant art institutions, there seems to be no obvious reason, while trying to think about new spaces of politics, why we should engage with "new media art" at all instead of just focusing on the precarious realities of cultural education in highly unequal and socially divided contexts such as Mexico. Yet art's public presence has remained significant in Mexico's neoliberal conjuncture, not least as an occupational horizon for young creative workers. Gerber and Pinochet (2012, 2015) notice the discursive instrumentalization of contemporary art by neoliberal governments, the latter having displaced the traditional model of the "man of letters" by the more versatile and business-oriented model of the contemporary artist $(2012,46)$. They also note the rise of figures like the curator and the arts administrator, which opened up previously unavailable horizons for young cultural workers of the neoliberal age. They argue that young creative workers are developing new forms of multimedia literacy through their engagement with the culture industries_including "the artworld"—and that such a "reading" is essential to their collective survival strategies in the context of new forms of precarity. Both within and without the "artworld", rather than a militant rebellion of the Net, we might be witnessing

a process by which ordinary people use images, sounds, objects, observations, information, and technological experiences to imagine the existence, shape, or form of an extensive and dispersed media infrastructure that cannot be physically observed by one person in its entirety. (Parks 2015, 359)

Antoni Abad's sitio*TAXI took place in Mexico City in 2004 (Parés 2014). Abad conceptualized the project and distributed cell phones among 17 taxi drivers who would send images, videos, audio and texts to the project's website. ${ }^{4}$ The point was not simply to 
distribute a technology for self-representation, but rather to gather participants every week to discuss and develop their editorial visions and contributions to the project. In this way, they configured new relations and dynamics around becoming aware of the infrastructural dimension of life and work in a megalopolis. Abad's ongoing project The Blind Point of View (BP) also invites users to appreciate the limitations of "normal vision" in relation to the infrastructural dimension of day-to-day life. At the heart of the project is a portable GPS-enabled camera phone to be used and shared by multiple participants, changing hands every week. Like sitio*TAXI, BP invites specific users-in this case the blind and visually impaired - to produce a nuanced, location-specific overview of the cityscape. Participants map and comment on accessibility and organize as activists and to lobby for increased and improved wayfinding facilities. The programmers of the project work together with the participants, adapting the mobile software and the website to their needs, while during weekly editorial meetings, participants discuss the content of webcasts.

Centro Multimedia's longstanding collaborator Eugenio Tisselli, who participated in sitio*TAXI, later orchestrated ojovoz.net, an open source mobile/web platform that allows a group of people to collaboratively create dynamic, audiovisual documentation and maps of their common interests and concerns. Among the various projects that Tisselli has developed through ojovoz.net there is Los ojos de la milpa (2012), or "the eyes of the milpa". Milpa is the name of Mexico's traditional subsistence-oriented agricultural plot and, following a similar methodology to that of Abad's projects, this one focuses on technological re-writing through the visual memory of rural communities. Several families from Santa María Tlahuitoltepec, in the Southern Mexican state of Oaxaca, used mobile phones to create an online collective memory during hard times for local agriculture. The point, once again, was not to "record" or politically represent a way of life on its way to irreversible extinction, but rather to "reveal the tense interweaving of the old and the new" (Tisselli, n.d.), in a sort of infrastructural, experimental and collaborative version of conjunctural analysis. While the digital commoning debate tends to focus on hospitality and caretaking, in its supposedly apolitical dimension or its uneasy relationship to the capitalist economy (Reijers and Ossewaarde 2018), what is most important for us is the infrastructural attitude that digital commoning undertakes. Such a non-essentialist, processual approach to the commons is a matter of critical cultural literacy because it opens a space for social learning through a democratic governance of common affairs. As noted above, infrastructure is a relational concept rather than a concrete object, something that flows from "people in practice", inhabiting a "mundane scale" of processes and changes regarded as "part of the building of organizations and production of knowledge" (Parks and Starosielski, 2015, 9). If cultural literacies are in transition in North and South, it is the post-autonomous practices of contemporary art that, through an infrastructural approach to digital commoning, create the terms for what we cannot fully anticipate.

\section{Conclusion}

We have attempted to theorize changing notions of cultural literacy as new spaces of politics in an ongoing historical conjuncture. We have sought to shed light on how, during the

${ }^{4}$ All of Antoni Abad's works are found in his website megafone.net. 
neoliberal conjuncture in Mexico, some artistic engagements with new technologies and media introduced commoning experiments and an infrastructural disposition as "terms for transition" for times of deep crisis. Such contributions signalled a progressive turn of cultural literacy. Through new media art projects such as Abad's and Tisselli's, Mexican people are creating what Berlant calls "placeholder forms for the commons to come" (Berlant 2016 , 408), that is, public spaces resulting from digitally-mediated reclamations of bits of nature and culture. What is being reinvented in this infrastructuralist view is the very concept of the public, which no longer involves "sovereignty as self-possession", but rather, the real on which we all precariously depend. This is about rethinking "obligations and practices of worlding and care" (Berlant 2016, 409). In this sense, our indirect response to the Zapatista CompArte Festival's call—with which we opened this article-is that art rebels most deeply and fruitfully when it does not let itself be merely instrumentalized as a tool or a vehicle for pre-established meanings or identities, and when it operates instead as a facilitator of new social meanings through an experimental engagement with material processes. Since this has not been done in any thorough or systematic way, we think that a more sustained and rigorous theorizing of artistic engagements with media and technology in contemporary Mexico has the potential to foster fruitful interdisciplinary dialogues between regional and global research on multiliteracies, critical studies of infrastructuring and philosophical approaches to art and politics.

\section{Disclosure statement}

No potential conflict of interest was reported by the authors.

\section{Funding}

This work was supported by Universidad Iberoamericana Mexico City, through the grant awarded to the research project Filosofía de la práctica editorial (2019-2021).

\section{ORCID}

Gabriela Méndez Cota (1) http://orcid.org/0000-0002-4566-4594

Alberto López Cuenca (D) http://orcid.org/0000-0003-2478-9416

\section{Bibliography}

Ackers, S., Arns, I., Hunger, F., and J. Lillemose, eds. 2006. The Hartware Guide to Irrational. Frankfurt am Main: Revolver.

Aedo, T. 2015. "Dialogan el arte y la tecnología. Laboratorio de Arte Alameda". In Itinerarios de la Cultura Contemporánea, edited by 17, Instituto de Estudios Críticos, 177-183. Ciudad de México: editorial diecisiete and Conaculta.

Amgott, N. 2018. "Critical literacy in \#digitalactivism: Collaborative choice and action". The International Journal of Information and Learning Technology 35(5): 329-341. doi:10.1108/IJILT05-2018-0060.

Barney, D., G. Coleman, C. Ross, J. Sterne, and T. Tembeck, eds. 2016. The Participatory Condition in the Digital Age. Minnesota: University of Minnesota Press.

Berlant, L. 2016. "The commons: Infrastructures for troubling times". Environment and Planning D: Society and Space 34(3): 393-419. 
Bishop, Claire. 2012. Artificial Hells. Participatory Art and the Politics of Spectatorship. Londres: Verso. Bollier, D., y H. Helfrich, eds. 2012. The Wealth of the Commons. A World Beyond Market and State. Amherst, Mass.: Levellers Press.

Bowker, G. C., and Star, S. L. 2002. "How to infrastructure". In Handbook of New Media: Social Shaping and Consequences of ICTS, edited by L. A. Lievrouw \& S. M. Livingstone, 151-162. London; Thousand Oaks, Calif: SAGE.

Conant, J. 2010. A Poetics of Resistance. The Revolutionary Public Relations of the Zapatista Insurgency. Oakland: AK Press.

Cuevas, M., and E. Abaroa. 2013. "Corporatocracy, democracy and social change (in Mexico and Beyond). A conversation on art and life". Third Text 27(1): 162-171. doi:10.1080/07055900.2012. 752196.

de Angelis, M. 2017. Omnia Sunt Communia: On the Commons and the Transformation to Postcapitalism. London: ZED Books.

Di Castro, A. 2006. "Art and new technology in Mexico: The national center for the arts". Leonardo 39 (4): 371-372. doi:10.1162/leon.2006.39.4.371.

Dias, B., Tourinho, I., Miranda, F., Olaya Parra O., Freitag, V. and Fernández T. 2017. “Looking at new trends and policies in Latin American art education". In The Palgrave Handbook of Global Arts Education, edited by G. Barton and M. Baguley, 157-170. London: Palgrave.

Dragona, D. 2014. "Counter-infrastructures, critical empowerment and emancipation in a networked world". Media N Journal 10(3). http://median.newmediacaucus.org/art-infrastructu res-information/counter-infrastructures-critical-empowerment-and-emancipation-in-a-networke d-world.

Dragona, D., and D. Charitos. 2018. Challenging Infrastructures. Alternative Networking \& the Role of Art. Ljubljana: Aksioma Institute for Contemporary Art.

Emmelhainz, I. 2016. La tiranía del sentido común. La reconversión neoliberal de México. Mexico City: Paradiso.

Enlace Zapatista. 2017. "Art, Resistance and Rebellion on the Net". Last modified July 15, 2017. http:// enlacezapatista.ezln.org.mx/2017/07/15/art-resistance-and-rebellion-on-the-net/.

Freire, P. 1970. Education for Critical Consciousness. London and New York: Continuum.

García Canclini, N. 1995. Hybrid Cultures. Strategies for Entering and Leaving Modernity. Minneapolis: University of Minnesota Press.

García Canclini, N. 2015. "Leer en papel y en pantallas: el giro antropológico". In Hacia una antropología de los lectores, edited by N. García Canclini, 138. Ciudad de México and Madrid: Fundación Telefónica, UAM-Iztapalapa and Ariel.

Geocomunes. 2018. "Collaborative cartography in defense of the commons". In This is Not an Atlas. A Global Collection of Counter-Cartographies, edited by Kollektiv Orangotango+, 100-103. Bielefeld: Verlag.

Gerber, V., and C. Pinochet. 2012. "La era de la colaboración. Mapa abreviado de nuevas estrategias artísticas". In Jóvenes, culturas urbanas y redes digitales, edited by N. García Canclini, F. Cruces, and M. Urteaga, 45-63. México y Madrid: UAM-Iztapalapa and Fundación Telefónica.

Gerber, V., and C. Pinochet. 2015. "Cómo leen los que escriben textos e imágenes". In Hacia una antropología de los lectores, edited by N. García Canclini, 171-227. México y Madrid: Fundación Telefónica, UAM-Iztapalapa and Ariel.

Giunta, A. 2014. ¿Cuándo empieza el arte contemporáneo? Buenos Aires: Fundación ArteBA.

Graham, B., and S. Cook. 2010. Rethinking Curating: Art After New Media. Cambridge, MA, and London: MIT Press.

Graham, J., Graziano, V., and S. Kelly. 2016. "The educational turn in art". Performance Research 21(6): 29-35. doi:10.1080/13528165.2016.1239912.

Hess, C. 2008. "Mapping new commons". Diss. presented at The Twelfth Biennial Conference of the International Association for the Study of the Commons, Cheltenham.

Illich, Iván. 1971. Deschooling Society. New York: Harper and Row.

Jasso, K., and D. Garza Usabiaga, eds. 2010. (Ready) Media: Hacia una arqueología de los medios y la invención en México. Mexico: Laboratorio de Arte Alameda, INBA and CONACULTA. 
Jiménez, D. 2019. "Hacia una pedagogía de la contingencia artística: una conversación con Mónica Amieva". Klastos, August 15, 2019. https://ladobe.com.mx/2019/08/hacia-una-pedagogia-de-lacontingencia-artistica-una-conversacion-con-monica-amieva/.

Kalman, J., and I. Reyes. 2017. "On literacy, reading, and learning to read in Mexico". Prospects 46, no. 3-4: 1-15. doi:10.1007/s11125-017-9406-9.

Karasti, H., Pipek, V., \& Bowker, G. 2018. "An afterword to 'infrastructuring and collaborative design'". Computer Supported Cooperative Work (CSCW) 27(2): 267-289. doi:10.1007/s10606-017-9305-x.

Kellner, D. and J. Share. 2005. "Toward critical media literacy: Core concepts, debates, organizations, and policy". Discourse: Studies in the Cultural Politics of Education 26(3): 369-386. doi:10.1080/ 01596300500200169.

Kester, G. H. 2004. Conversation Pieces. Community and Communication in Modern Art. Berkeley: University of California Press.

Lane, J., and R. Domínguez. 2003. "Digital Zapatistas". TDR/The Drama Review 47(2): 129-144.

Lind, M. 2007. "The collaborative turn". In Taking the Matter Into Common Hands. Contemporary Art and Collaborative Practices, edited by J. Billing et al. London: Black Dog Publishing.

Linebaugh, P. 2014. Stop! Thief: The Commons, Enclosures and Resistance. Oakland: Pm Press.

Maet, F. 2013. "About the destruction, continuation, and transformation of art". CLCWeb: Comparative Literature and Culture 15(3). doi:10.7771/1481-4374.2243.

Marroquín Parducci, A. 2017. "De los medios a las mediaciones. Orígenes y diálogos posteriores". In De los medios a las mediaciones de Jesús Martín Barbero, 30 años después, edited by M. de Moragas, J. L. Terrón and O. Rincón, 21-42. Bellaterra: Institut de la Comunicació, Universitat Autonoma de Barcelona.

Martínez-Torres, M. E. 2001. "Civil society, the internet, and the Zapatistas". Peace Review 13(3): 347355. doi:10.1080/13668800120079045.

Martínez Velázquez, A., ed. 2017. Derechos digitales en México: ganadores y perdedores de la reforma en telecomunicaciones. Ciudad de Mexico: Horizontal.

New London Group. 1996. "A pedagogy of multiliteracies: Designing social futures". Harvard Educational Review 66(1): 652-690.

Ollé-Laprune, P. 2011. México: visitar el sueño. Ciudad de México: Fondo de Cultura Económica.

O'Toole, G. 2003. "A new nationalism for a new era: The political ideology of Mexican neoliberalism". Bulletin of Latin American Research 22(3): 269-290. doi:10.1111/1470-9856.00078.

Parés, R., ed. 2014. Antoni Abad. megafone.net/2004-2014. Barcelona: Museu d'Art.

Parks, L. 2015. "'Stuff you can kick": Toward a theory of media infrastructures". In Between Humanities and the Digital, edited by Patrik Svensson and David Theo Goldberg, 355-373. Cambridge \& London: The MIT Press.

Parks, L., and N. Starosielski. 2015. "Introduction". In Signal Traffic. Critical Studies of Media Infrastructures, edited by L. Parks and N. Starosielski, 1-27. Urbana, Chicago, and Springfield: University of Illinois Press.

Peters, J. D. 2015. The Marvelous Clouds. Toward a Philosophy of Elemental Media. Chicago and London: University of Chicago Press.

Poblete, J., ed. 2018. New Approaches to Latin American Studies. New York: Routledge.

Poster, M, 2006. "Culture and new media: A historical view". In Handbook of New Media. Social Shaping and Social Consequences of ICTS, edited by L. A. Lievrouw and S. Livingstone, 134-140. London, Thousand Oaks \& New Dehli: Sage.

Quintero Álvarez, L. 2010. “Centro Multimedia. Una Mirada Bajo Cuatro Interrupciones”. Interartive 23. Accessed December 23, 2019. http://interartive.org/2010/07/centro-multimedia-mexico/.

Reijers, W. and M. Ossewaarde. 2018. "Digital commoning and its challenges". Organization 25(6): 819-824.

Rhizomatica. n.d. "About Rhizomatica". Accessed August 25, 2017. https://www.rhizomatica.org/ about/.

Rivera Garza, C. 2013. Los muertos indóciles. Necroescrituras y desapropiación. Barcelona and México: Tusquets.

Rodríguez, H. 2016. "SubalterNet: Networked practices from Latin America in response to the internet". Media-N Journal of the New Media Caucus. Accessed December 19, 2019. http://median. 
newmediacaucus.org/mestizo-technology-art-design-and-technoscience-in-latin-america/ subalternet-networked-practices-from-latin-america-in-response-to-the-internet/.

Rutten, K., Rodman, G. B., and R. Soetaert. 2013. "Cultural studies and critical literacies". International Journal of Cultural Studies 16(5): 443-456. doi:10.1177/1367877912474544.

Schmilchuk, G., A. Rosas Mantecón, and M. Piccini, eds. 2000. Recepción artística y consumo cultural. México: INBA, CENIDIAP/Casa Juan Pablos.

Shliakhovchuk, E. 2019. "After cultural literacy: New models of intercultural competency for life and world in a VUCA world". Educational Review. doi:10.1080/00131911.2019.1566211.

Sholette, G. and B. Stimson, eds. 2007. Collectivism After Modernism. The Art of Collective Imagination After 1945. Minneapolis: University of Minnesota Press.

Smith, T. 2009. What is Contemporary Art? Chicago, Ill.: University of Chicago Press.

Tisselli, E. 2016. "Algunas ideas sobre reescritura tecnológica". In Primer encuentro nacional sobre reescritura tecnológica en México, edited by N. Cortés and E. Tisselli, 9-17, Mexico: Centro Multimedia.

Tisselli, E. n.d. "The eyes of the milpa". Accessed March 12, 2019. http://sautiyawakulima.net/oaxaca/ about.php?!=2

Trigos-Carrillo, L., and R. Rogers. 2017. "Latin American influences on multiliteracies: From epistemological diversity to cognitive justice". Literacy Research: Theory, Method, and Practice 66(1): 373388. doi:10.1177/2381336917718500.

Wolf, Matt. 2006. "Rhizome.org”. Art Libraries Journal 31(1): 47-48. doi:10.1017/S0307472200014383. 